OPEN ACCESS

\author{
Indonesian Journal of Human Nutrition \\ P-ISSN 2442-6636 \\ E-ISSN 2355-3987 \\ www.ijhn.ub.ac.id \\ Artikel Hasil Penelitian
}

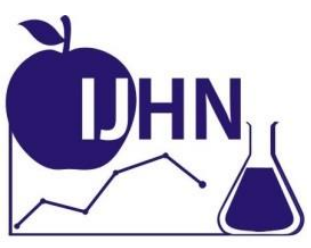

\title{
Perbedaan Tingkat Konsumsi Energi, Lemak, Cairan, dan Status Hidrasi Mahasiswa Obesitas dan Non Obesitas
}

\section{(Difference of Consumption Level of Energy, Fat, Liquid and Hydration Status of Obese and Non Obese Students)}

\author{
Annas Buanasita $^{1 *}$, Andriyanto $^{1}$, Indah Sulistyowati ${ }^{2}$ \\ ${ }^{1}$ Akademi Gizi Surabaya \\ 2 Jurusan S1 Ilmu Gizi STIKES Surabaya \\ *Alamat korespondensi, E-mail: sannasita@yahoo.com
}

Diterima: / Direview: / Dimuat: September 2014 / November 2014 / Juni 2015

\begin{abstract}
Abstrak
Dehidrasi merupakan kondisi kekurangan cairan tubuh karena jumlah cairan yang keluar lebih banyak daripada jumlah cairan yang masuk. Terdapat 37,3\% remaja asupan cairannya kurang dari $90 \%$ kebutuhannya atau risiko dehidrasi. Dehidrasi dapat menjadi faktor risiko terjadinya obesitas pada anak dan remaja di samping asupan energi dan lemak yang berlebihan. Tujuan penelitian untuk mengetahui perbedaan tingkat konsumsi energi, lemak dan cairan serta status hidrasi pada mahasiswa obesitas dan non obesitas di Akademi Gizi Surabaya. Penelitian ini merupakan studi observasional analitik yaitu membanding antara kelompok obesitas dan non obesitas atau case control study. Populasi dalam penelitian seluruh mahasiswa Akademi Gizi Surabaya sebanyak 170 mahasiswa baik yang obes maupun normal. Sampel yang diambil sebanyak 31 mahasiswa obesitas (total population) dan 31 mahasiswa non obesitas (simple random sampling). Pengambilan data asupan energi, lemak dan cairan dilakukan dengan repeated recall dan status hidrasi dilakukan dengan tes urine, sedangkan uji statistik yang digunakan untuk melihat perbedaan dua kelompok dengan uji Chai Square. Hasil penelitian menunjukkan bahwa ada perbedaan tingkat konsumsi lemak, cairan, dan status hidrasi pada mahasiswa obesitas dan non obesitas di Akademi Gizi Surabaya. Mahasiswa yang obesitas memiliki tingkat konsumsi energi dengan kategori di atas normal yang lebih tinggi dibandingkan mahasiswa non obesitas. Tingkat konsumsi lemak pada mahasiswa non obesitas dengan kategori defisit berat lebih tinggi $(32,3 \%)$ dibandingkan kelompok obesitas $(3,2 \%)$. Tingkat konsumsi cairan pada mahasiswa obesitas dengan kategori defisit berat lebih tinggi $(64,5 \%)$ dibandingkan non obesitas $(19,4 \%)$. Status hidrasi menunjukkan mahasiswa obesitas banyak mengalami dehidrasi yaitu 21 responden $(67,7 \%)$, dibandingkan mahasiswa non obesitas yaitu 6 responden $(19,4 \%)$. Diharapkan mahasiswa terutama yang obesitas harus mendapatkan cukup informasi tentang pola makannya terutama asupan cairan karena ini akan mempengaruhi konsentrasi belajar. Perlu adanya penelitian lanjutan antara asupan cairan dan status hidrasi dengan status kesehatan pada mahasiswa.
\end{abstract}

Kata kunci : energi, lemak, cairan, status hidrasi, obesitas 


\begin{abstract}
Dehydration is a condition of the body dehydrated because the amount of fluid comes out more than the amount of fluid intake. There are 37,3\% of teens who drink less than $90 \%$ of requirements or had dehydration risk. Dehydration could be a risk of obesity besides excessive intake of energy and fat. The purpose of this study is to determine differences in the level of energy, fat and fluids consumption, and hydration status in obese and non-obese students in the Nutrition Academy of Surabaya. This was an analytical observational study which designed tried to find the differences between the two groups (obese and non obese group) or "case control study". The population was Nutrition Academy of Surabaya, consisting 170 students, and the samples comprised 31 students of obese (total obese students) and 31 students non-obese (simple random sampling). Repeated Food Recall was used to get energy, fat and fluid consumption. Urine test was used to know the hydration status. Statistical test used Chai Square Test. The results showed that there was a difference in the level of energy consumption, fat and fluids, and hydration status in obese and non-obese students in the Nutrition Academy of Surabaya. Students who are obese have higher percentage of energy consumption whose category more than normal compared to those who are non-obese. The percentage of fat consumption in non-obese students with severe deficiency was higher (90,9\%) compared to those with obesity (9,1\%). The percentage of fluid intake in obese students with severe deficiency level was higher $(76,9 \%)$ than those of non-obese students $(23,1 \%)$. In hydration status, many obese students were dehydrated, consisting of 21 respondents $(77,8 \%)$, compared to non-obese students which are 6 respondents $(22,2 \%)$. To get better health and students achievements, students have to get enough information about the advantages of fluid consumption., especially those who are obese. It is suggested that further research is conducted to see the relationship between fluids consumption and dehydration with health status of the students.
\end{abstract}

Keywords: fluids consumption, hydration status, obese and non-obese

\section{PENDAHULUAN}

Air merupakan salah satu unsur gizi serta komponen utama dalam tubuh manusia. Air sebagai salah satu zat gizi makro esensial mempunyai beberapa fungsi antara lain untuk pelarut dan alat angkut, sebagai katalisator, pelumas, fasilitator pertumbuhan, pengatur suhu tubuh dan peredam benturan [1]. Air dinyatakan esensial karena tubuh tidak dapat menghasilkan air untuk memenuhi kebutuhan tubuh, oleh sebab itu air harus diperoleh dari luar tubuh [2]. Agar proses metabolisme dalam tubuh berjalan dengan baik dibutuhkan masukan cairan setiap hari untuk menggantikan cairan yang hilang.

Kandungan air tubuh berbeda antar manusia tergantung pada proporsi jaringan otot dan jaringan lemak. Tubuh yang mengandung lebih banyak jaringan otot mengandung lebih banyak air. Secara normal, dalam satu hari tubuh akan kehilangan cairan melalui ginjal, kulit, paruparu maupun feses. Untuk menjaga agar kondisi dan fungsi cairan tubuh tidak terganggu, kehilangan cairan tersebut harus diganti. Jika tubuh tidak cukup mendapatkan air atau terjadi kehilangan air sekitar 5\% dari berat badan (pada anak, remaja dan dewasa) maka keadaan ini dikenal dengan istilah dehidrasi.

Dehidrasi merupakan kondisi kekurangan cairan tubuh karena jumlah cairan yang keluar lebih banyak daripada jumlah cairan yang masuk. Menurut Asian Food Information Centre [3], dehidrasi terbagi menjadi tiga kelompok yaitu dehidrasi ringan, dehidrasi sedang, dan dehidrasi tingkat berat. Dehidrasi dapat mengganggu keseimbangan dan pengaturan suhu tubuh dan pada tingkat yang sudah sangat berat bisa berujung pada penurunan kesadaran dan koma.

Dehidrasi dapat menjadi faktor risiko terjadinya obesitas pada anak dan remaja [4]. Hal ini disebabkan oleh adanya ketidakseimbangan elektrolit dalam tubuh yang memacu meningkatnya nafsu makan dan asupan makanan yang kaya lemak sehingga asupan cairan dalam tubuh menurun. Lieberman, et al. [5] menjelaskan bahwa dehidrasi pada remaja 
obesitas menyebabkan penurunan fungsi kognisi dan mood, juga meningkatkan kelelahan sehingga tubuh menjadi lemas dan malas untuk beraktivitas fisik. Kebiasaan minum sebelum makan dapat menjadi alternatif cara untuk mencegah dehidrasi dan terapi penurunan berat badan pada remaja obesitas. Penelitian di Virginia pada orang obesitas menunjukkan bahwa konsumsi air sebelum makan dapat menurunkan asupan makan sampai $13 \%$ [6].

Pemilihan jenis konsumsi cairan yang mengandung gula tinggi dapat menjadi faktor obesitas karena minuman bergula tinggi menyumbang energi yang cukup banyak bagi tubuh [7] sehingga beberapa penelitian menganjurkan untuk mengganti konsumsi minuman manis berenergi tinggi tersebut dengan konsumsi air putih pada orang obesitas.

Hasil penelitian tentang kebiasaan minum remaja dan asupan cairan remaja perkotaan di Bogor menunjukkan bahwa terdapat 37,3\% remaja yang minum kurang dari 8 gelas per hari dan sebesar $24,1 \%$ remaja asupan cairannya kurang dari 90\% kebutuhan [4]. Survey NHANES II (1999-2002) di Amerika menunjukkan perbedaan konsumsi cairan baik dari makanan maupun minuman pada remaja yang obesitas dan non obesitas diketahui lebih banyak pada remaja obesitas sebesar 2,4 liter. Hal ini didukung oleh hasil survey NHANES III (2005-2006) yang menemukan bahwa konsumsi total cairan pada remaja obesitas lebih tinggi dibanding remaja non obesitas yaitu 2,2 liter berbanding 1,9 liter.

Meskipun konsumsi cairannya sudah lebih tinggi pada remaja obesitas, namun dilihat dari kebutuhan cairan yang seharusnya sebesar 2,4 3,3 liter, pemenuhan konsumsi cairan pada remaja obesitas tergolong masih kurang dari standar kebutuhan cairan. Hal ini disebabkan kandungan air di dalam sel lemak orang yang mengalami obesitas lebih rendah daripada kandungan air dalam sel otot. Perbandingan antara air dan lemaknya berbanding 50\%: 50\% lebih rendah dibandingkan dengan orang yang berat badannya normal sehingga orang obesitas lebih mudah kekurangan cairan.
Terjadinya penumpukan lemak tubuh pada orang obesitas dapat meningkatkan berat badan tanpa menambah kandungan air dalam tubuh [8]. Oleh karena itu kebutuhan air bagi orang obesitas disarankan 2 gelas lebih banyak dari standar kebutuhan dibandingkan orang normal, selain karena faktor lebih mudah dehidrasi, konsumsi air yang cukup diketahui juga membantu menurunkan berat badan sehingga dapat menjadi cara baru untuk menurunkan kejadian obesitas [3].

Sebagai mahasiswa gizi, seyogyanya memberikan contoh dengan memiliki postur tubuh ideal serta status gizi normal kepada masyarakat dengan cara pemasukan energi disesuaikan atau disamakan dengan pengeluaran energinya. Belum ada penelitian sebelumnya tentang dehidrasi terhadap kejadian obesitas di Akademi Gizi Surabaya. Oleh karena itu peneliti ingin mengetahui perbedaan tingkat konsumsi energi, lemak dan cairan, serta status hidrasi pada mahasiswa obesitas dan non obesitas.

\section{METODE PENELITIAN}

Penelitian ini bersifat observasional analitik yang bertujuan untuk mempelajari perbedaan tingkat konsumsi energi, lemak, dan cairan serta status hidrasi antara mahasiswa obesitas dan non obesitas sehingga desain penelitian ini adalah case control study.

Populasi pada penelitian adalah semua mahasiswa Akademi Gizi Surabaya tingkat 1 dan 2 sejumlah 170 mahasiswa. Sementara mahasiswa tingkat 3 tidak diambil datanya karena sedang menempuh PKL di luar kota. Pengambilan responden diawali dengan melakukan screening terhadap seluruh mahasiswa untuk menentukan status gizi. Status gizi ditentukan berdasarkan klasifikasi Indeks Massa Tubuh (IMT) untuk orang Asia menurut WHO. Responden yang memiliki IMT $\geq 23,00 \mathrm{~kg} / \mathrm{m}^{2}$ dikategorikan obesitas dan yang memiliki IMT $18,00-22,99 \mathrm{~kg} / \mathrm{m}^{2}$ dikategorikan non obesitas. Jumlah responden dalam penelitian ini diperoleh 31 responden obesitas dan 31 responden non obesitas, sehingga total responden dalam penelitian ini adalah 62 responden. Responden 
kelompok obesitas diambil secara total responden dan untuk kelompok non obesitas diambil secara simple random sampling. Data yang diambil yaitu karakteristik mahasiswa yang meliputi umur, tingkat semester, dan jenis kelamin diambil dengan metode wawancara. Konsumsi energi, lemak, dan cairan adalah jumlah rata-rata intake zat-zat gizi tersebut yang dikonsumsi oleh mahasiswa dalam waktu 3 hari yang berbeda. Tingkat konsumsi energi, lemak, dan cairan tersebut diperoleh dengan melakukan wawancara dengan metode food recall selama $3 \times 24$ jam dengan adanya jeda hari. Analisis asupan atau intake zat gizinya menggunakan software nutrisurvey 2007, kemudian dihitung rata-rata total konsumsi energi selama $3 \times 24$ jam.

Konsumsi cairan adalah jumlah rata-rata intake cairan yang masuk dalam tubuh yang berasal dari minuman (air mineral, soft drink, minuman berasa) dan makanan (kuah sayur, kadar air pada buah dan sayur). Data asupan zat gizi (energi, lemak) dibandingkan dengan AKG (Angka Kecukupan Gizi) untuk orang Indonesia tahun 2005 lalu dikategorikan menjadi 4 yaitu di atas normal bila $>120 \%$, normal bila $90-110 \%$, defisit ringan bila $80-89 \%$, defisit sedang bila 70-79\%, dan defisit berat bila $<70 \%$ AKG.

Status hidrasi adalah suatu kondisi yang menggambarkan jumlah cairan dalam tubuh seseorang yang dapat diketahui dari pengujian warna urin dengan grafik warna urin. Pengambilan sampel urin pda pagi hari dengan menggunakan botol kaca bening. Setelah urin didapat, kemudian dicocokkan warnanya menggunakan grafik warna urin di bawah sinar lampu neon putih atau di bawah sinar matahari untuk menentukan kadar hidrasinya. Ketentuan warna urin yaitu apabila 1-3 maka responden terhidrasi dengan baik, 4-6 maka responden kurang terhidrasi dengan baik (dehidrasi ringan) dan 78 maka responden mengalami dehidrasi [3].

Pengolahan dan analisis data dilakukan dengan program komputer dengan bantuan SPSS for windows untuk mengetahui perbedaan tingkat konsumsi energi, lemak, dan cairan serta status hidrasi menggunakan uji statistik chisquare. Apabila tidak memenuhi kriteria uji chisquare, maka akan dianalisis dengan Fisher Exact Test. Oleh karena itu untuk keperluan uji statistik data tingkat konsumsi yang semula 4 kategori yaitu di atas normal, normal, defisit ringan, defisit sedang, dan defisit berat akan dimampatkan menjadi 2 kategori yaitu normal dan tidak normal.

\section{HASIL PENELITIAN \\ Karakterisitik Responden Penelitian}

Berdasarkan Tabel 1 dapat dilihat bahwa dari 62 mahasiswa dengan rentang usia 18-20 tahun dari kelompok obesitas maupun non obesitas memiliki jumlah yang sama yaitu 28 responden $(50 \%)$, sedangkan mahasiswa dari kelompok non obesitas dengan rentang usia 2124 tahun juga memiliki jumlah yang sama yaitu 3 responden $(50 \%)$ (Tabel 1).

Tabel 1. Distribusi Frekuensi Berdasarkan Karakteristik Responden

\begin{tabular}{lcc}
\hline \multicolumn{1}{c}{ Karakteristik Responden } & $\begin{array}{c}\text { Obesitas } \\
\mathbf{n}(\boldsymbol{\%})\end{array}$ & $\begin{array}{c}\text { Non Obesitas } \\
\mathbf{n}(\boldsymbol{\%})\end{array}$ \\
\hline Umur & & \\
$18-20$ & $28(50,0)$ & $28(50,0)$ \\
$21-24$ & $3(50,0)$ & $3(50,0)$ \\
Tingkat (semester) & & \\
I (II) & $17(56,6)$ & $13(43,4)$ \\
II (IV) & $14(43,7)$ & $18(56,3)$ \\
Jenis kelamin & & \\
Perempuan & $29(49,2)$ & $30(50,8)$ \\
Laki-laki & $2(66,6)$ & $1(33,4)$ \\
& & \\
\hline
\end{tabular}


Tabel 1 menunjukkan bahwa dari 62 sampel adalah mahasiswa tingkat semester IV berjumlah 32 responden yang terdiri dari 18 responden $(56,2 \%)$ dari kelompok non obesitas dan 14 responden $(43,8 \%)$ dari kelompok obesitas, sedangkan hampir setengahnya adalah mahasiswa tingkat semester II berjumlah 30 responden yang terdiri dari 17 responden $(56,7 \%)$ dari kelompok obesitas. Persentase mahasiswa yang obesitas lebih banyak pada mahasiswa semester II.

Jenis kelamin responden hampir seluruhnya berjenis kelamin perempuan sebanyak 29 responden $(49,2 \%)$ dari kelompok obesitas dan 30 responden $(50,8 \%)$ dari kelompok non obesitas, sedangkan responden yang berjenis kelamin laki-laki sebanyak 2 responden $(66,7 \%)$ dari kelompok obeitas dan 1 responden $(33,3 \%)$ dari kelompok non obesitas.

\section{Tingkat Konsumsi Energi, Lemak, dan Cairan}

Berdasarkan Tabel 2 dapat dicermati bahwa dari 62 mahasiswa yang dijadikan responden yang memiliki tingkat konsumsi energi normal berjumlah 33 mahasiswa terdiri dari kelompok obesitas sebanyak 22 responden (67\%) dan 11 responden (33\%) dari kelompok non obesitas. Responden yang memiliki tingkat konsumsi energi defisit ringan berjumlah 6 mahasiswa terdiri dari kelompok obesitas sebanyak 2 responden (33\%) dan 4 responden (67\%) dari kelompok non obesitas. Terlihat bahwa dari mahasiswa dengan tingkat konsumsi energi di atas normal, semuanya (100\%) adalah kelompok obesitas.
Untuk tingkat konsumsi lemak terlihat di Tabel 2 bahwa dari 62 mahasiswa sebagai responden yang memiliki tingkat konsumsi lemak di atas normal $100 \%$ berasal dari kelompok obesitas. Namun demikian, ada beberapa responden dari kelompok obesitas juga memiliki tingkat konsumsi lemak yang defisit ringan, sedang maupun berat, dengan persentase lebih kecil dibandingkan dengan kelompok yang tidak obesitas.

Tingkat konsumsi cairan menunjukkan bahwa mahasiswa yang memiliki tingkat konsumsi cairan kategori defisit berat berjumlah 26 mahasiswa terdiri dari kelompok obesitas sebanyak 20 responden $(76,9 \%)$ dan 6 responden $(23,1 \%)$ dari kelompok non obesitas. Mahasiswa yang memiliki tingkat konsumsi cairan normal berjumlah 20 mahasiswa terdiri dari kelompok non obesitas sebanyak 17 responden $(85,0 \%)$ dan 3 responden $(15,0 \%)$ dari kelompok obesitas. Konsumsi cairan dengan kategori defisit berat sebagian besar berasal dari kelompok mahasiswa yang obesitas $(76,9 \%)$.

\section{Status Hidrasi}

Tabel 3 dapat dilihat bahwa dari 62 mahasiswa hampir setengahnya mengalami dehidrasi yaitu 27 mahasiswa terdiri dari 21 responden $(77,8 \%)$ dari kelompok obesitas dan 6 responden $(22,2 \%)$ dari kelompok non obesitas. Responden yang memiliki status hidrasi kurang berjumlah 16 responden yang terdiri dari 7 responden $(43,8 \%)$ dari kelompok obesitas dan 9 responden $(56,2 \%)$ dari kelompok non obesitas. 
Tabel 2. Distribusi Frekuensi Tingkat Konsumsi Energi Responden

\begin{tabular}{lcc}
\hline \multicolumn{1}{c}{ Tingkat Konsumsi } & $\begin{array}{c}\text { Obesitas } \\
\mathbf{n}(\boldsymbol{\%})\end{array}$ & $\begin{array}{c}\text { Non Obesitas } \\
\mathbf{n}(\boldsymbol{\%})\end{array}$ \\
\hline Energi & & \\
Di atas normal & $5(100,0)$ & $0(0,0)$ \\
Normal & $22(67,0)$ & $11(33,0)$ \\
Defisit Ringan & $2(33,0)$ & $4(67,0)$ \\
Defisit Sedang & $1(10,0)$ & $9(90,0)$ \\
Defisit Berat & $1(13,0)$ & $7(88,0)$ \\
Lemak & & \\
Di atas normal & $7(100,0)$ & $0(0,0)$ \\
Normal & $18(75,0)$ & $6(25,0)$ \\
Defisit Ringan & $1(11,1)$ & $8(88,9)$ \\
Defisit Sedang & $4(36,4)$ & $7(63,6)$ \\
Defisit Berat & $1(9,1)$ & $10(90,9)$ \\
Cairan & & \\
Normal & $3(15,0)$ & $17(85,0)$ \\
Defisit Ringan & $3(42,9)$ & $4(57,1)$ \\
Defisit Sedang & $5(55,6)$ & $4(44,4)$ \\
Defisit Berat & $20(76,9)$ & $6(23,1)$ \\
\hline
\end{tabular}

Tabel 3 Distribusi Frekuensi Status Hidrasi Responden

\begin{tabular}{lcc}
\hline \multicolumn{1}{c}{ Status Hidrasi } & $\begin{array}{c}\text { Obesitas } \\
\mathbf{n}(\boldsymbol{\%})\end{array}$ & $\begin{array}{c}\text { Non Obesitas } \\
\mathbf{n}(\boldsymbol{\%})\end{array}$ \\
\hline Baik & $3(15,8)$ & $16(84,2)$ \\
Kurang & $7(43,8)$ & $9(56,2)$ \\
Dehidrasi & $21(77,8)$ & $6(22,2)$ \\
\hline
\end{tabular}

\section{Perbedaan Tingkat Konsumsi Energi, Lemak, Cairan, dan Status Hidrasi Responden antara Kelompok Obesitas dan Non Obesitas}

Tabel 4 menunjukkan bahwa sebagian besar mahasiswa memiliki tingkat konsumsi energi normal yaitu berjumlah 33 responden yang terdiri dari 22 responden $(67,0 \%)$ dari kelompok obesitas dan 11 responden $(33,0 \%)$ dari kelompok non obesitas. Hasil uji statistik Fisher Exact Test menunjukkan bahwa ada perbedaan tingkat konsumsi energi mahasiswa obesitas dan non obesitas di Akademi Gizi Surabaya. Sementara itu untuk tingkat konsumsi lemak menunjukkan bahwa hampir sebagian mahasiswa memiliki tingkat konsumsi lemak tidak normal yaitu berjumlah 38 responden yang terdiri dari 25 responden $(64,8 \%)$ dari kelompok non obesitas dan 13 responden $(34,2 \%)$ dari kelompok obesitas. Hasil uji statistik Fisher
Exact menunjukkan bahwa ada perbedaan tingkat konsumsi lemak mahasiswa obesitas dan non obesitas di Akademi Gizi Surabaya. Demikian juga untuk tingkat konsumsi cairan responden, berdasarkan Tabel 4 tersebut di atas menunjukkan bahwa mahasiswa yang memiliki tingkat konsumsi cairan normal berjumlah 20 responden terdiri dari kelompok non obesitas sebanyak 17 responden (85\%) dan 3 responden $(15 \%)$ dari kelompok obesitas. Mahasiswa yang memiliki tingkat konsumsi cairan tidak normal berjumlah 42 responden terdiri dari 28 responden $(66,7 \%)$ dari kelompok obesitas dan 14 responden $(33,3 \%)$ dari kelompok non obesitas. Hasil uji statistik Fisher Exact menunjukkan bahwa ada perbedaan tingkat konsumsi cairan mahasiswa obesitas dan non obesitas. Dan untuk status hidrasi, dari Tabel 4 tersebut di atas pula terlihat bahwa sebagian besar mahasiswa mengalami dehidrasi yaitu 
berjumlah 27 responden yang terdiri dari 21 responden $(77,8 \%)$ dari kelompok obesitas dan 6 responden $(22,2 \%)$ dari kelompok non obesitas. Berdasarkan hasil uji Fisher Exact menunjukkan bahwa ada perbedaan status hidrasi mahasiswa obesitas dan non obesitas di Akademi Gizi Surabaya.

Tabel 4. Perbedaan Tingkat Konsumsi Energi, Lemak, Cairan, dan Status Hidrasi antara Kelompok Obesitas dan Non-Obesitas

\begin{tabular}{lccc}
\hline \multicolumn{1}{c}{ Variabel } & Obesitas & Non Obesitas & p-value $(C I)^{*}$ \\
\hline Tingkat konsumsi energi & $22(67,0)$ & $11(33,0)$ & $0,01(95 \%)$ \\
- Normal & $9(29,0)$ & $22(71,0)$ & \\
- Tidak normal & & & \\
Tingkat konsumsi lemak & $18(75,0)$ & $6(25,0)$ & $0,04(95 \%)$ \\
- Normal & $13(34,2)$ & $25(64,8)$ & \\
- Tidak normal & & & \\
Tingkat konsumsi cairan & $3(15,0)$ & $17(85,0)$ & $0,00(95 \%)$ \\
- Normal & $28(66,6)$ & $14(33,4)$ & \\
- Tidak normal & & & \\
Status Hidrasi & $3(15,8)$ & $16(84,2)$ & $0,00(95 \%)$ \\
- Normal & $28(65,1)$ & $15(35,9)$ & \\
- Dehidrasi & & & \\
\hline
\end{tabular}

*Fisher Exact Test

\section{PEMBAHASAN \\ Karakteristik Responden}

Kelompok mahasiswa berumur 18 tahun ke atas merupakan masa remaja yang aktif dan membutuhkan asupan makanan atau zat gizi yang mengandung karbohidrat, protein, lemak, vitamin, dan mineral serta cairan untuk menunjang aktifitas sehari-harinya. Kebutuhan akan zat gizi merupakan kebutuhan paling utama untuk perkembangan remaja, dengan bertambahnya usia terkadang tingkat konsumsi makanan yang tidak terkontrol bisa menyebabkan terjadinya obesitas pada remaja. Untuk itu pada remaja usia 18 tahun ke atas, zat gizi pada makanan seperti karbohidrat, protein, lemak, vitamin, mineral serta cairan harus dipantau konsumsinya agar tidak menyebabkan terjadinya obesitas.

Menurut Hardinsyah dan Tampubolon [9], kecukupan gizi adalah rata-rata asupan gizi harian yang cukup untuk memenuhi kebutuhan gizi bagi hampir semua orang sehat dalam kelompok umur, jenis kelamin, dan fisiologis tertentu. Nilai asupan harian zat gizi yang diperkirakan dapat memenuhi kebutuhan gizi mencakup $50 \%$ orang sehat dalam kelompok umur, jenis kelamin, dan fisiologis tertentu disebut dengan kebutuhan gizi.

Tingkat semester merupakan jenjang pendidikan yang tempuh oleh mahasiswa dalam menyelesaikan perkuliahan. Mahasiswa tingkat semester lebih tinggi dalam pengetahuan dan memahami tentang makanan yang dikonsumsi, lebih banyak memiliki informasi yang didapat dalam menempuh pendidikan atau kuliah, sehingga mahasiswa memahami mana makanan yang harus dikonsumsi untuk kebutuhan sehari - hari.

Pendidikan diperlukan untuk mendapat informasi misalnya hal-hal yang menunjang kesehatan sehingga dapat meningkatkan kualitas hidup. Pendidikan dapat mempengaruhi seseorang termasuk juga perilaku seseorang akan pola hidup terutama dalam memotivasi untuk sikap berperan serta dalam pembangunan. Pada umumnya, semakin tinggi tingkat pendidikan seseorang maka semakin mudah menerima informasi sehingga semakin banyak pengetahuan yang dimiliki, sebaliknya pendidikan yang kurang akan menghambat perkembangan sikap seseorang terhadap nilainilai yang baru diperkenalkan. 
Pada jenis kelamin perempuan sering ditemukan masalah obesitas, hal ini disebabkan oleh perubahan hormonal pada wanita. Pada wanita dalam hal mengkonsumsi makanan terkadang tidak terkontrol sehingga dapat menyebabkan obesitas, disamping itu juga disebabkan oleh perubahan sirkulasi haid. Selain alasan tersebut, faktor aktifitas yang kurang juga dapat menyebabkan terjadinya kejadian obesitas pada wanita.

Jenis kelamin tampaknya ikut berperan dalam timbulnya obesitas. Meskipun dapat terjadi pada kedua jenis kelamin, tetapi obesitas lebih umum dijumpai pada wanita. Obesitas pada wanita disebabkan oleh pengaruh faktor endokrin karena kondisi ini muncul pada saat adanya perubahan hormonal.

\section{Tingkat Konsumsi Energi, Lemak, dan Cairan Responden}

Berdasarkan hasil repeated recall terlihat bahwa mahasiswa dari kelompok obesitas memiliki frekuensi makan makanan utama lebih sering (4-5 kali) daripada kelompok non obesitas (3-4 kali), hal ini kiranya yang menyumbangkan energi lebih banyak pada kelompok obesitas. Makanan utama adalah sumber karbohidrat yang relatif tinggi dan implikasinya dapat menyumbangkan energi yang relatif besar pada tubuh [10]. Lemak merupakan penyumbang energi terbesar dibandingkan zat gizi lainnya. Satu (1) gram lemak mengandung 9 kkal, dibandingkan karbohidrat dan protein yang menghasilkan 4 kkal per gramnya. Anjuran konsumsi lemak tidak melebihi $30 \%$ dari total energi yang dianjurkan [11].

Mahasiswa yang berasal dari kelompok obesitas memiliki frekuensi makan makanan yang digoreng lebih sering (2-3 kali) daripada yang non obesitas. Diantaranya adalah tahu goreng, ote-ote, roti goreng dan bahkan ada yang hampir setiap hari makan nasi goreng. Secara tidak langsung kelebihan lemak ini akan ditimbun dalam tubuh dan terbukti sekarang ini kelompok ini memiliki berat badan yang lebih. Meskipun demikian, ada sebagian kecil mahasiswa dari kelompok non obesitas yang mengkonsumsi gorengan, namun frekuensinya hanya $<2$ kali, tidak sesering kelompok obesitas.

Tingkat konsumsi cairan menunjukkan bahwa kebutuhan cairan atau air pada mahasiswa obesitas dan non obesitas sama yaitu sebanyak $2300 \mathrm{ml}$ menurut AKG (Angka Kecukupan Gizi). Pada mahasiswa obesitas, kebutuhan akan konsumsi cairan seharusnya lebih tinggi yaitu $2400 \mathrm{ml}$ atau 2 gelas lebih banyak dibandingkan mahasiswa non obesitas karena pada mahasiswa yang mengalami obesitas kebutuhan akan cairan sangat dibutuhkan sebab mahasiswa yang obesitas sering mengeluarkan banyak keringat sehingga membutuhkan cairan yang lebih. Pada kenyataannya, dibandingkan dengan kebutuhan menurut AKG yaitu 2,3 liter masih banyak mahasiswa obesitas yang mengalami kekurangan cairan. Apalagi jika dibandingkan dengan kebutuhan yang lebih tinggi sekitar 2,4 liter, maka yang terjadi adalah semakin banyak mahasiswa obesitas yang akan mengalami kekurangan cairan. Hal ini senada dengan hasil penelitian tentang kebiasaan minum remaja dan asupan cairan remaja perkotaan di Bogor menemukan bahwa terdapat $37,3 \%$ remaja yang minum kurang dari 8 gelas per hari dan sebesar $24,1 \%$ remaja asupan cairannya kurang dari 90\% kebutuhan [12]. Berbeda dengan data Survey NHANES II (1999-2002) di Amerika menemukan perbedaan konsumsi cairan baik dari makanan maupun minuman pada remaja yang obesitas dan non obesitas diketahui lebih banyak pada remaja obesitas sebesar 2,4 liter.

\section{Status Hidrasi}

Status hidrasi pada mahasiswa obesitas cukup banyak yaitu 21 mahasiswa $(77,8 \%)$ hal ini disebabkan oleh mahasiwa yang obesitas volume air keluar dalam tubuh banyak sehingga dapat menyebabkan dehidrasi lebih karena kehilangan cairan yang dikeluarkan dari tubuh. Pada obesitas, air tubuh total lebih rendah dibandingkan dengan non obesitas karena kandungan air di dalam sel lemak lebih rendah daripada kandungan air di dalam sel otot. Dengan demikian, mahasiswa obesitas lebih 
mudah mengalami kekurangan cairan atau air dibandingkan dengan mahasiswa non obesitas.

\section{Perbedaan Tingkat Konsumsi Energi, Lemak, Cairan, dan Status Hidrasi antara Mahasiswa Obesitas dan Non Obesitas}

Kebutuhan tingkat konsumsi energi bagi status gizi yang obesitas maupun non obesitas tidaklah sama dikarenakan kebutuhan energi bagi mahasiswa obesitas lebih besar dibandingkan non obesitas. Hal ini disebabkan oleh berat badan pada mahasiswa obesitas mempengaruhi asupan makanan yang dikonsumsi. Jika kebutuhan energi mahasiswa obesitas dan non obesitas disamakan yaitu sebanyak 2250 kkal menurut AKG (Angka Kecukupan Gizi), akan terjadi ketidakseimbangan kebutuhan energi dengan konsumsi energinya sehingga menyebabkan tingkat konsumsi energi normal bagi mahasiswa obesitas padahal seharusnya lebih tinggi dari kebutuhan energi yang dianjurkan. Ada 5 mahasiswa obesitas yang memiliki tingkat konsumsi diatas normal, sedangkan pada mahasiswa non obesitas tidak ada yang memiliki tingkat konsumsi diatas normal.

Mahasiswa obesitas mengonsumsi makanan sumber karbohidrat yang menyumbang energi cukup tinggi. Contoh makanan yang dikonsumsi dengan frekuensi 2-3x sehari dengan porsi yang cukup banyak adalah nasi, roti, mie serta gula dan sirup. Pada mahasiswa non obesitas, konsumsi makanan sumber karbohidrat seperti nasi dikonsumsi sebanyak $2 \mathrm{x}$ sehari dengan porsi sedang yaitu 100-150 g, roti dan mie 2x per minggu, gula cukup 1x sehari dan sirup cukup $2 x$ per minggu sehingga tingkat konsumsi energi pada mahasiswa obesitas jauh lebih banyak pada mahasiswa non obesitas. Hal ini sangat dipengaruhi oleh pola makannya yaitu frekuensi dan porsi makanan yang dikonsumsinya disamping dari tuntutan sel-sel yang harus dihidupinya sesuai berat badannya.

Obesitas terjadi karena adanya ketidakseimbangan antara energi yang masuk dengan energi yang keluar dan merupakan akumulasi simpanan energi yang berubah menjadi lemak. Apabila remaja mengonsumsi makanan dengan kandungan energi sesuai yang dibutuhkan tubuhnya maka tidak ada energi yang disimpan. Sebaliknya remaja dalam mengonsumsi energi melebihi kebutuhan tubuh maka kelebihan energi akan disimpan sebagai cadangan energi [13]. Cadangan energi secara berkesinambungan ditimbun setiap hari yang akhirnya menimbulkan obesitas.

Kebutuhan konsumsi lemak bagi mahasiswa yang obesitas maupun non obesitas merupakan kebutuhan makanan bagi semua orang. Kebutuhan lemak sebesar 95\% merupakan kebutuhan untuk tubuh manusia baik yang mengalami obesitas maupun non obesitas. Karena yang membedakan tingkat konsumsi dan frekuensi lemak yang dimakan oleh mahasiswa, hasil penelitian menunjukkan bagi mahasiwa yang mengalami obesitas jumlah lemak yang dikonsumsi seperti makanan yang digoreng, bakso dan makanan yang berminyak terkadang berlebihan dan frekuensi yang dikonsumsi dalam sehari terkadang 2-3 kali mengkonsumsinya sehingga menyebabkan penimbunan lemak pada tubuh dan menyebabkan obesitas. Pada mahasiswa non obesitas dalam mengonsumsi makanan seperti makanan yang digoreng dan bakso setiap harinya cukup 1 kali dan tidak berlebihan sehingga tingkat kebutuhan lemak pada mahasiswa yang obesitas maupun non obesitas sama tetapi yang membedakan adalah frekuensi mengonsumsinya.

Obesitas sebagai kondisi dimana massa sel lemak berlebihan dan tidak hanya didefinisikan dengan berat badan saja karena pada orang-orang dengan masa otot besar dapat dianggap overweight tanpa peningkatan sel-sel lemak [14]. Lemak merupakan penyumbang energi terbesar dibandingkan zat gizi lainnya. Satu gram lemak mengandung 9 kkal, dibandingkan karbohidrat dan protein yang menghasilkan 4 kkal per gramnya. Anjuran konsumsi lemak tidak melebihi $30 \%$ dari total energi yang dianjurkan [11]. Menurut Dietary Reference Intake's (DRIs) tahun 2002, berdasarkan laporan dari National Cholesterol Education Program (NECP) menyatakan untuk asupan lemak bagi anak-anak dan remaja usia 4- 
18 tahun perlu mengonsumsi lemak 25-35\% dari total energi. DRIs merekomendasikan bahwa anak-anak dan remaja mengkonsumsi sedikit lemak jenuh dan lemak trans. Sumber utama lemak jenuh dan lemak trans pada remaja adalah susu, daging, keju, margarin, kue, donat, dan es krim. NECP juga merekomendasikan konsumsi kolesterol tidak lebih dari $300 \mathrm{mg}$. Sumber kolesterol bagi remaja adalah telur, daging, susu, ayam, dan keju [15].

Kebutuhan cairan atau air pada mahasiswa obesitas dan non obesitas sama yaitu sebanyak $2300 \mathrm{ml}$ menurut AKG (Angka Kecukupan Gizi). Pada mahasiswa obesitas, kebutuhan akan konsumsi cairan seharusnya lebih tinggi yaitu $2400 \mathrm{ml}$ atau 2 gelas lebih banyak dibandingkan mahasiswa non obesitas. Mahasiswa yang mengalami obesitas kebutuhan akan cairan sangat dibutuhkan sebab mahasiswa yang obesitas sering mengeluarkan banyak keringat sehingga membutuhkan cairan yang lebih. Pada kenyataannya, dibandingkan dengan kebutuhan menurut AKG yaitu 2,3 liter masih banyak mahasiswa obesitas yang mengalami kekurangan cairan, sebanyak 20 mahasiswa $(64,5 \%)$. Apalagi jika dibandingkan dengan kebutuhan yang lebih tinggi sekitar 2,4 liter, maka yang terjadi adalah semakin banyak mahasiswa obesitas yang akan mengalami kekurangan cairan. Mahasiswa non obesitas sebagian besar memiliki tingkat konsumsi yang normal sebanyak 17 mahasiswa (85\%), sedangkan 28 mahasiswa $(66,7 \%)$ obesitas memiliki tingkat konsumsi cairan yang tidak normal. Kebutuhan cairan pada mahasiswa obesitas dan non obesitas juga dipengaruhi oleh tingkat aktifitas sehari-hari. Pada mahasiswa obesitas terkadang aktifitas sedikit tetapi asupan energi dan luas permukaan tubuh sangat membutuhkan cairan, sedangkan pada mahasiswa non obesitas terkadang aktivitas sehari hanya membutuhkan cairan paling sedikit 1 liter [16].

Kebutuhan air sangat bervariasi antar individu. Besarnya kebutuhan dipengaruhi oleh usia, jenis kelamin, jenis pekerjaan, suhu dan kelembaban lingkungan serta aktivitas fisik. Penentuan kebutuhan air untuk orang sehat dapat didasarkan pada umur, berat badan, asupan energy, dan luas permukaan tubuh. Konsumsi air yang cukup pada orang dewasa dalam keadaan basal adalah sebanyak 2 liter dalam 24 jam. Bagi orang dewasa, pengeluaran urin 2 liter sehari dapat melarutkan berbagai sisa metabolisme melalui urin dan pembuangannya dengan lancar. Bagi orang dewasa untuk minum air paling sedikit 1 liter lebih banyak dari apa yang dibutuhkan rasa haus kita. Gunanya untuk mengoptimalkan fungsi berbagai organ tubuh terutama jantung, pembuluh darah, otak, dan saraf [17].

Pada status hidrasi pada mahasiswa obesitas cukup banyak yaitu 21 mahasiswa $(77,8 \%)$ hal ini disebabkan oleh pada mahasiwa yang obesitas volume air keluar dalam tubuh banyak sehingga dapat menyebabkan dehidrasi lebih akibat kehilangan cairan yang dikeluarkan dari tubuh. Pada obesitas, air tubuh total lebih rendah dibandingkan dengan non obesitas, hal ini dikarenakan kandungan air di dalam sel lemak lebih rendah daripada kandungan air di dalam sel otot. Dengan demikian, mahasiswa obesitas lebih mudah mengalami kekurangan cairan atau air dibandingkan dengan mahasiswa non obesitas. Mahasiwa yang non obesitas tingkat hidrasi baik sebanyak 16 mahasiswa $(84,2 \%)$ karena cairan yang dikeluarkan dalam tubuh cukup sedikit sehingga tidak mengalami hidrasi. Terkadang pada mahasiswa yang obesitas pada suhu udara yang tinggi lebih banyak mengeluarkan cairan yang banyak bila dibandingkan pada mahasiswa yang non obesitas. Dengan demikian kebutuhan cairan atau air bagi mahasiswa obesitas sebaiknya 2 gelas lebih banyak dibandingkan kondisi non obesitas. Hal ini disebabkan oleh asupan air putih yang lebih banyak meningkatkan oksidasi (pembakaran lemak), sedangkan pada mahasiwa non obesitas kebutuhan cairan atau air dalam sehari membutuhkan minimal 2 liter atau setara dengan 8 gelas per hari.

Air merupakan sebagian zat pembentuk tubuh manusia. Tergantung jumlah lemak yang terdapat dalam tubuh, proporsi air ini berbeda pada setiap orang [1]. Salah satu fungsi cairan dalam tubuh adalah pengatur suhu. Semakin 
luas permukaan tubuh, semakin besar kehilangan panas melalui kulit. Lemak di bawah kulit berperan sebagai bahan isolasi yang mengurangi kecepatan panas hilang dari tubuh [3].

Dehidrasi dapat terjadi bila keluaran airnya adalah cairan yang hipotonik, yaitu volume air yang keluar jauh lebih besar dari jumlah natrium yang keluar. Hal ini akan mengakibatkan peningkatan tonisitas plasma oleh karena adanya peningkatan kadar natrium plasma (hipernatremia). Akibat peningkatan tonisitas plasma, air intrasel akan bergerak menuju ekstrasel sehingga volume cairan intrasel berkurang yang disebut sebagai dehidrasi [17].

\section{KESIMPULAN}

Tingkat konsumsi energi dan lemak dengan kategori di atas normal persentasenya lebih tinggi pada mahasiswa obesitas dibandingkan mahasiswa non obesitas. Tingkat konsumsi cairan pada mahasiswa obesitas dengan kategori defisit berat lebih tinggi dibandingkan non obesitas. Status hidrasi menunjukkan mahasiswa obesitas banyak mengalami dehidrasi, dibandingkan mahasiswa non obesitas. Hasil pengujian statisitik terlihat bahwa ada perbedaan tingkat konsumsi energi, lemak dan cairan serta status hidrasi pada mahasiswa obesitas dan non obesitas di Akademi Gizi Surabaya.

\section{SARAN}

Berkenaan akan pentingnya asupan cairan pada remaja, terutama juga untuk mendapatkan prestasi belajar yang optimal, maka perlu adanya program penyuluhan khusus pada remaja tentang pentingnya konsumsi cairan bagi tubuh sehingga tidak akan mengalami kekurangan cairan atau dehidrasi, terutama bagi remaja yang obesitas. Karena dehidrasi dapat menyebabkan berbagai bahaya kesehatan seperti menurunkan konsentrasi belajar, kurang fokus dalam menerima pelajaran, gangguan kesehatan lainnya. Oleh karena itu, perlu adanya penelitian lanjutan yang mencoba menganalisis hubungan antara status konsumsi cairan tubuh dan dehidrasi dengan gangguan kesehatan.

\section{DAFTAR RUJUKAN}

1. Yuniastuti A. Gizi dan Kesehatan. Yogyakarta: Graha Ilmu; 2008.

2. Amstrong, LE. Rationale for Renewed Emphasis on Dietary Water Intake. Proceedings of the 1st Annual Scientific Meeting on Hydration for Health. Hydration or Health. Paris. 201;7-8.

3. Hardinsyah, Budi IS, et al. Air Bagi Kesehatan, Edisi Kedua. Jakarta: Centra Communications; 2012.

4. Gustam, Hardinsyah, Briawan D. Faktor Risiko Dehidrasi pada Remaja dan Dewasa. (skripsi). Bogor: Departemen Gizi Masyarakat FEMA IPB; 2012.

5. Lieberman, Harris R. Hydration and Cognition: A Critical Review and Recommendations for Future Research. Journal of the American College of Nutrition. 2007; Vol. 26 (5): 555S-561S.

6. Davy, Brenda M, Elizabeth $\mathrm{AD}$, et al. Water Consumption Reduces Energy Intake at a Breakfast Meal in Obesity Older Aduls. J Am Diet Assoc. 2008; 108(7): 1236-1239.

7. Daniels, Melissa C, Barry M. Popkin. The Impact Of Water Intake on Energy Intake and Weight Status: A Systematic Review. Nutr Rev. 2010; 68(9): 505-521.

8. Batmanghelidj F. Air untuk Menjaga Kesehatan dan Menyembuhkan Penyakit. Jakarta: Gramedia Pustaka Utama; 2007.

9. Hardinsyah, Tampubolon V. Kecukupan Energi, Protein, Lemak, dan Serat Makanan. Jakarta: Widyakarya Nasional Pangan dan Gizi VIII; 2004.

10. Almatsier, Sunita. Prinsip Dasar Ilmu Gizi. Jakarta: PT. Gramedia Pustaka Utama; 2009.

11. Soetjiningsih. Tumbuh Kembang Remaja dan Permasalahannya. Jakarta: Agung Seto; 2004.

12. Briawan D, Hardinsyah et al. Studi Kebiasaan Minum dan Status Hidrasi pada Remaja dan dewasa di Wilayah Ekologi yang Berbeda. Bogor: Perhimpunan 
Peminat Gizi dan Pangan Indonesia (Pergizi Pangan), Departemen Gizi Masyarakat FEMA IPB; 2009.

13. Pritasari. Obesitas dan Penanggulangannya. Jakarta: Penebar Swadaya; 2006.

14. Fauci, AS, et al. Obesity. In: Harrison's Manual of Medicine $17^{\text {th }}$ Edition. New York: The McGraw-Hill; 2009.
15. Brown, JE. Nutrition Through the Life Cycle. $2^{\text {nd }}$ edition. California: Thomson Wadsworth; 2005.

16. Proboprastowo SM dan Dwiriyani CM. Angka Kecukupan Air dan Elektrolit. Jakarta: Widya Karya Nasional Pangan dan Gizi; 2004.

17. Hardinsyah, Budi IS, et al. Air Bagi Kesehatan, Edisi Kedua. Jakarta: Centra Communications; 2012. 